\title{
Diffuse large B-cell lymphoma, leg type: A case report
}

\author{
Diffüz büyük B hücreli lenfoma, bacak tipi: Bir olgu sunumu
}

๑ Begüm Ünlü, ๑ Ayça Cordan Yazıcı, ๑ Güliz İkizoğlu, ๑ Yasemin Yuyucu Karabulut*, (1) Anıl Tombak**

Mersin University Faculty of Medicine, Department of Dermatology, Mersin, Turkey

*Mersin University Faculty of Medicine, Department of Pathology, Mersin, Turkey

**Mersin University Faculty of Medicine, Department of Hematology, Mersin, Turkey

\begin{abstract}
Primary cutaneous diffuse large B-cell lymphoma, leg type is a primary cutaneous B cell lymphoma of aggressive behavior and regarded as a unique entity. We reported a 74 years old female patient who presented with rapidly growing nodules with an ulcer on her left leg for four months. Skin biopsy revealed pathologic findings consistent with diffuse large B-cell lymphoma. We want to emphasize that malignant entities should always be in mind in the differential diagnosis of rapidly growing nodules, plaques, and non-healing ulcers.

Keywords: Lymphoma, leg type ulcer, B cell
\end{abstract}

Öz

Diffüz büyük B hücreli lenfoma, bacak tipi, primer kütanöz lenfomaların nadir görülen, kötü prognozlu bir alt tipidir. Yetmiş dört yaşında kadın hasta, sol bacağında, 4 ay önce ortaya çıkan, hızlı büyüyen, şş̧likler ve yaralar yakınmasıyla dermatoloji kliniğimize başvurdu. Tanı alınan deri biyopsi materyalinin histopatolojik inceleme ile konuldu. İyileşmeyen bacak ülserlerinde, nodül ve plak lezyonlarında, malign hastalıklardan şüphelenilerek biyopsi alınmalıdır.

Anahtar Kelimeler: Lenfoma, bacak tipi, ülser, B hücreli

\section{Introduction}

Primary cutaneous diffuse large B-cell lymphoma, leg type (DLBCL-LT) is a rare subtype of cutaneous lyphomas. Tumors are usually located on a leg. This entity is generally seen in elderly patients and has an unfavorable prognosis ${ }^{1,2}$. A skin biopsy should be performed to confirm the diagnosis. Diverse histological patterns are reported in the literature ${ }^{3,4}$. There are no randomized controlled data to guide treatment. Topical-intralesional medications, radiotherapy chemotherapy and surgery are some of the treatment options $s^{5,6}$.

\section{Case Report}

A 74-year-old woman was referred to our dermatology department with rapidly growing nodules on her left lower leg, Lesions have appeared 4 months ago. Medical history revealed hypertension and vertigo, she was on hydrochlorothiazide, irbesartan, metoprolol, and pramipexole. The patient presented with 3 erythematous tumoral lesions on the anterior aspect of her left lower leg (Figure 1). There is a large plaque which was $7 \mathrm{~cm}$ in diameter, composed of smaller nodules and had an ulcer on top of it. This tumor completely involves the anterior surface of

Address for Correspondence/Yazıșma Adresi: Begüm Ünlü MD, Mersin University Faculty of Medicine, Department of Dermatology, Mersin, Turkey Phone: +90 5314267635 E-mail: begumunlu@mersin.edu.tr Received/Geliş Tarihi: 22.04.2018 Accepted/Kabul Tarihi: 31.05.2019 ORCID: orcid.org/0000-0001-8428-6613 
ankle and extends to the dorsal foot. There are also smaller 2 nodules on the anterior aspect of her left lower leg that are $2 \mathrm{~cm}$ and 3, 5 $\mathrm{cm}$ in diameter. Constitutional symptoms such as, fever, night sweats, pruritus or weight loss was absent. Neither hepatosplenomegaly nor lymphadenopathy was detected in physical examination. All laboratory tests were negative, including a full blood count, biochemistry, routine urine examination, except hemoglobin (hemoglobin $11.2 \mathrm{~g} / \mathrm{dL}$, normal range: $11.7-16.1 \mathrm{~g} / \mathrm{dL}$ ) and creatinine levels (creatinine $1.89 \mathrm{mg} /$ $\mathrm{dL}$, normal range: $0.5-0.9 \mathrm{mg} / \mathrm{dL}$ ). Serology tests for viruses (human immunodeficiency virus and hepatitis $B$ and $C$ viruses) were negative, except anti HBS-105.7 positive and anti immunoglobulin G (HBC lgG)-0.012 positive. In magnetic resonance imaging of the left lower leg, the tumor was found to extend to bone tissue, without bone infiltration. Histopathological sections showed superficial and deep dermal infiltration of atypical lymphoid cells with extensive irregular nuclear contour, partially vesicular nucleus, prominent nucleoli, narrow eosinophilic cytoplasm and frequent mitosis, causing focal ulceration in the epidermis (Figure 2). Immunohistochemically, these cells showed diffuse cytoplasmic staining with CD20 (Figure 3), BCL2. T lymphocyte markers were very sparse. The Ki67 proliferation index was detected as $70 \%$.

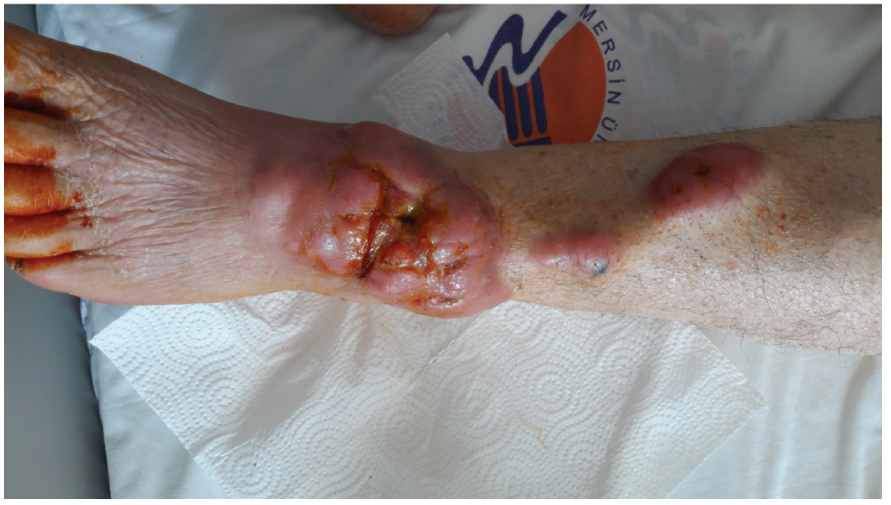

Figure 1. Three erythematous tumoral lesions on the anterior aspect of her leftleg. The largest nodule was $7 \mathrm{~cm}$ in diameter and had an ulcer on top

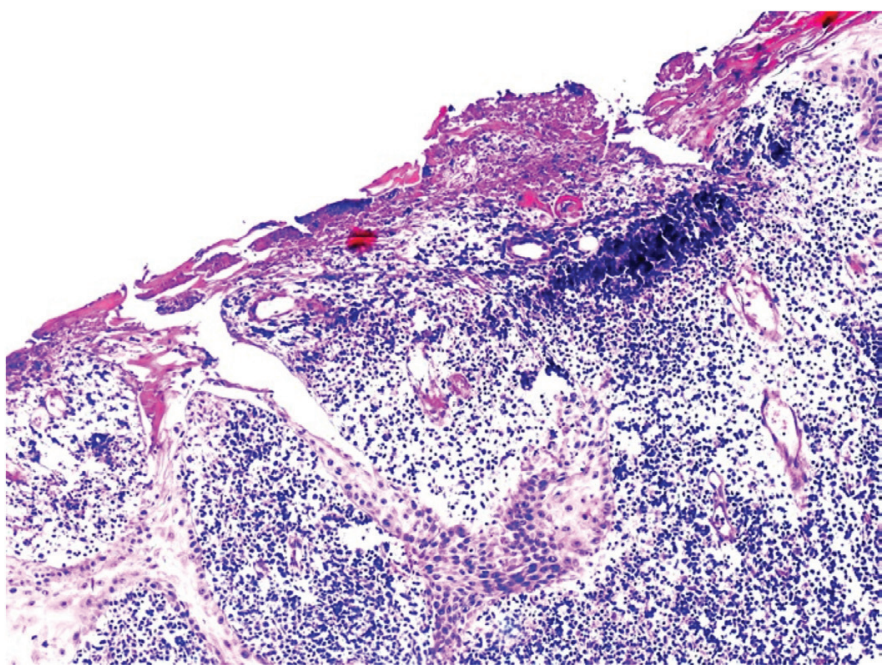

Figure 2. Diffuse dermal infiltration of atypically mphoid cells and focal ulceration (Hematoxylin-eosine dye x100)
Further staging evaluation and treatment were planned by hematology department of our hospital. Positron emission tomography-computed tomography (PET-CT) showed tumor and inguinal lymphadenopathy on the left side (SUV $V_{\max }$ :4.48). The patient was started on systemic chemotherapy with rituximab combined with "Doxorubicin,

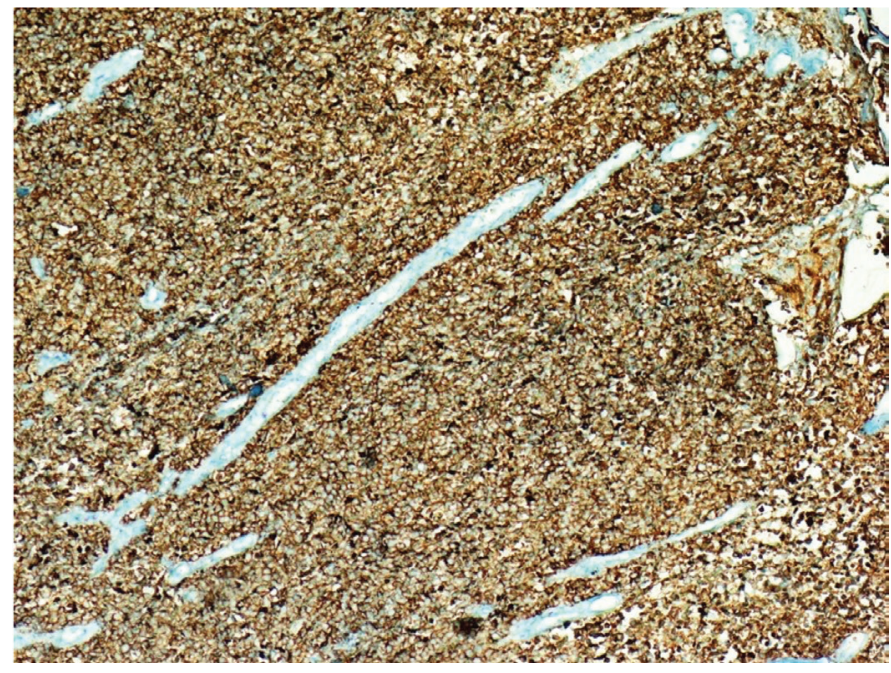

Figure 3. Diffuse cytoplasmic staining with CD20 (CD20 dye x100)

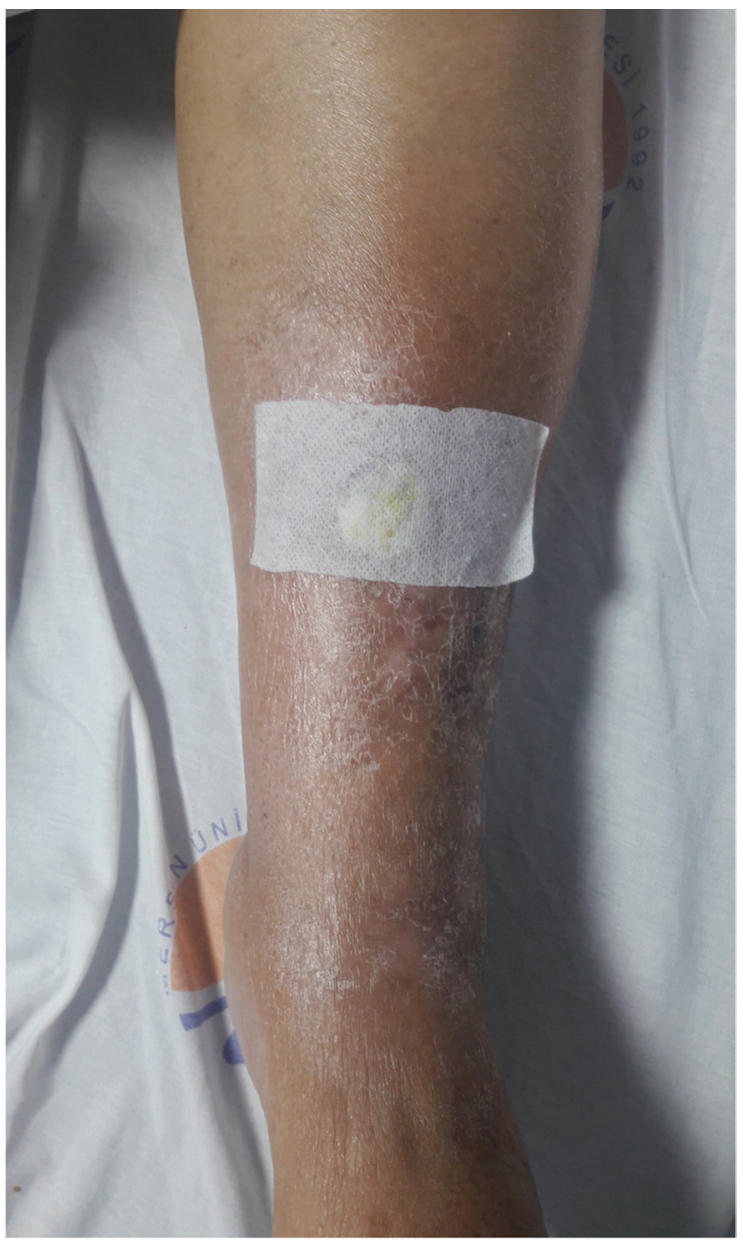

Figure 4. An ulcer emerged after regression of the tumor on upper part of leg. Other tumors healed with postlesional hyperpigmentation 
Cyclophosphamide, Vincristine, and Prednisone" (R-CHOP) for six cycles. After chemotherapy, tumors regressed. Control PET-CT imaging showed complete response to treatment. An ulcer emerged after regression of the tumor on upper part of leg. Other tumors healed with postlesional hyperpigmentation (Figure 4). Patient is in remission for 2 years.

She gave us a written informed consent for publication of this case report in a journal which is read worldwide or an online journal.

\section{Discussion}

Primary cutaneous B-cell lymphomas are not uncommon forms of primary cutaneous lymphomas and account for approximately $25 \%$ of all primary cutaneous lymphomas ${ }^{1,2}$. DLBCL-LT represents approximately $5 \%-10 \%$ of cutaneous B-cell lymphomas ${ }^{7}$. DLBCLLT is described according to World Health Organization/European Organization for Research and Treatment of Cancer classification of cutaneous lymphomas ${ }^{8,9}$.The other subtypes of primary cutaneous B-cell lymphoma are primary cutaneous marginal-zone B-cell lymphoma, primary cutaneous follicle-center lymphoma, primary cutaneous DLBCLLT, Primary cutaneous DLBCL, other' .

The clinical presentation is a rapidly growing nodule or plaque, that can be solitary or multiple and may have surface ulceration as in our case $\mathrm{e}^{1,2,8}$ (Figure 1). The lesions show a bluish-reddish multicolored rainbow pattern $^{10}$. In $80 \%$ of the patients these lesions are located on the leg ${ }^{2,8}$. Rarely DLBCL-LT may manifest on bilateral legs or non-leg regions of the body ${ }^{2,8}$. In 10\%-15\% of cases, lesions are presented on non-leg regions such as trunk, head, neck, and upper arms ${ }^{11}$. It affects elderly patients mostly ${ }^{2,8,12}$. Median age of DLBCL-LT patients is found as 79 years 8 . Our patient was 74 years old. In contrast to other subtypes of primary cutaneous B-cell lymphomas, primary cutaneous DLBCL-LT, has an unfavorable prognosis ${ }^{1,2}$. Five year survival rate is only $58 \%$ due to frequent extracutaneous progression, including central nervous system involvement $2,13,14$. Most patients (55\%-70\%) have recurrence, and in a substantial number of cases (40\%) extracutaneous progression may occur $^{2,3}$. Some authors reported poorer prognosis for tumors located on the leg and the presence of multiple skin tumors at diagnosis; but this result is not duplicated in other studies ${ }^{2,3,12}$. Somatic mutations in MYD88 and inactivation of 9p21.3, reported to be associated with a worse prognosis in some studies ${ }^{1-3} .9 \mathrm{p} 21.3$ is associated with CDKN2A gene that encodes the tumor suppressor genes p16 and P14ARF ${ }^{1-3}$.

The diagnosis first requires a biopsy of the skin lesions. After confirmation of diagnosis, history, physical examination, laboratory testing, imaging and bone marrow examination should be performed to evaluate extracutaneous disease.

In histopathologic examination of DLBCL-LT, there are monotonous, dense, non-epidermotropic infiltrate composed of monomorphic B-lymphocytes with mostly round and large cell morphology which are described as immunoblasts, centroblasts or pleomorphic B-cells extending through dermis and often into the subcutis ${ }^{2-4}$. Mitotic figures are frequently seen in immunoblast nuclei, ${ }^{3,15}$. If there is ulceration on the lesion, epidermis will be spared. Rarely epidermotropism may be seen in histopathologic examination ${ }^{2-4}$. Rare unusual histological variants of DLBCL-LT are sclerosing pattern, geographic necrosis, anaplastic cell morphology, angioinvasion, starry-sky pattern, mixed inflammatory infiltrate, spindle cell pattern, histiocytoid morphology, vascular-like areas, multilobated cells, perineural invasion, and epidermotropic pattern ${ }^{4}$. Unusual patterns may cause significant diagnostic challenge. In such cases, clinical correlation, use of appropriate immunohistochemical stains can help to make the correct diagnosis. In immunohistopathologic examination, standard B-cell markers (CD20, Pax-5, and CD79a), BCl-6, BCl-2, MUM-1, FOX-P1, IgM, P63 are mostly positive. CD10 (germinal center marker) is usually negative ${ }^{2,8}$. In this case, infiltrating lymphocytes are stained positive for $\mathrm{BCl} 2, \mathrm{CD} 20$ (Figure 3) and negative for CD10. BCl-2-negative cases are categorized as "primary cutaneous DLBCL, other" ${ }^{\prime \prime, 12}$. There is not a significant difference between leg type and the other group ${ }^{12}$. MUM-1, FOX-P1, IgM, and P63, which are negative markers in primary cutaneous follicle center lymphoma, also help in differential diagnosis ${ }^{3,4}$. Mostly disorganized, bended or multilobulated centrocytes, that are known as cleaved cells, with lesser quantity of admixed lymphocytes are the main features of primary cutaneous follicle center lymphoma in contrast to DLBCL-LT ${ }^{3,4}$. There are no randomized controlled data to guide treatment. In case of solitary and localized lesions, surgery and radiation therapy can be chosen for a curative therapeutic approach ${ }^{6}$. Radiotherapy is safe and effective for localized lesions ${ }^{5,6}$. In advanced cutaneous lymphoma radiotherapy alone has a role in symptom palliation ${ }^{6}$. If lesions are only thin plaques, topical treatment with high-potency corticosteroids and intralesional administration of interferon alpha or rituximab can also be used $^{5}$. In the case of multiple and symptomatic lesions systemic drug treatment is needed ${ }^{5,6}$. First choice in treatment of advanced disease is accepted as rituximab in most of the reports ${ }^{5}$. In case of metastasis and recalcitrant disease chemotherapy should be added to therapy ${ }^{5}$. Our patient received rituximab and chemotherapy.

DLBCL-LT is described as a distinct clinical subtype of primary cutaneous B-cell lymphomas. A biopsy should be performed to rule out a neoplasm in patients who has nodules or plaques with or without ulcers. Further reports are needed to clarify unique clinical features, morphology, immunophenotype, and molecular characteristics of DLBCL-LT.

\section{Ethics}

Informed Consent: We have taken informed consent of patient.

Peer-review: Externally and internally peer-reviewed.

\section{Authorship Contributions}

Surgical and Medical Practices: B.Ü., A.C.Y., A.T., Y.Y.K., Concept: B.Ü., Design: B.Ü., Data Collection or Processing: B.Ü., Analysis or Interpretation: B.Ü., Literature Search: B.Ü., Writing: B.Ü., Y.Y.K., G.I.

Conflict of Interest: No conflict of interest was declared by the authors.

Financial Disclosure: The authors declared that this study received no financial support.

\section{References}

1. Kempf W, Kazakov DV, Mitteldorf C: Cutaneous lymphomas: an update. Part 2: B-cell lymphomas and related conditions. Am J Dermatopathol 2014;36:197-208.

2. Hope CB, Pincus LB: Primary cutaneous B-cell lymphomas. Clin Lab Med 2017;37:547-74.

3. Hope $C B$, Pincus LB: Primary cutaneous B-cell lymphomas with large cell predominance-primary cutaneous follicle center lymphoma, diffuse large 
B cell lymphoma, leg type and intravascular large B-cell lymphoma. Semin Diagn Pathol 2017;34:85-98.

4. Plaza JA, Kacerovska D, Stockman DL, et al: The histomorphologic spectrum of primary cutaneous diffuse large B-cell lymphoma: A study of 79 cases. Am J Dermatopathol 2011;33:649-55.

5. Nicolay JP, Wobser M: Cutaneous B-cell lymphomas-pathogenesis, diagnostic workup, and therapy. J Dtsch Dermatol Ges 2016;14:1207-24.

6. Pedretti $\mathrm{S}$, Urpis $\mathrm{M}$, Leali C: Primary cutaneous non-Hodgkin lymphoma: Results of a retrospective analysis in the light of the recent ILROG guidelines. Tumori 2017 Feb 14:0.

7. Paulli M, Lucioni M, Maffi A, Croci GA, Nicola M, Berti E: Primary cutaneous diffuse large B-cell lymphoma (PCDLBCL), leg-type and other: An update on morphology and treatment. G Ital Dermatol Venereol 2012;147:589-602.

8. Kodama K, Massone C, Chott A, Metze D, Kerl H, Cerroni L: Primary cutaneous large B-cell lymphomas: clinicopathologic features, classification, and prognostic factors in a large series of patients. Blood 2005;106(7):24917

9. Willemze R, Jaffe ES, Burg G, et al: WHOEORTC classification for cutaneous lymphomas. Blood 2005;105:3768-85.
10. Suárez AL, Pulitzer M, Horwitz S, et al: Primary cutaneous B-cell lymphomas: Part I. Clinical features, diagnosis, and classification. J Am Acad Dermatol 2013;69:329-40.

11. Selva $R L$, Violetti $S A$, Delfino $C$, et al: A literature revision in primary cutaneous B-cell lymphoma. Indian J Dermatol 2017;62:146-57.

12. Zinzani PL, Quaglino P, Pimpinelli N, et al: Prognostic factors in primary cutaneous B-cell lymphoma: The Italian Study Group for cutaneous lymphomas. J Clin Oncol 2006;24:1376-82.

13. Süss $A$, Simon JC, Sticherling M: Primary cutaneous diffuse large Bcell lymphoma, leg type, with the clinical picture of chronic venous ulceration. Acta Derm Venereol 2007;87:169-70.

14. Querfeld C, Guitart J, Kunzel TM, Rosen ST. Primary cutaneous lymphomas: A review with current treatment options. Blood Rev 2003;17:131-42.

15. Suárez AL, Pulitzer M, Horwitz S, et al: Primary cutaneous B-cell lymphomas: Part I. Clinical features, diagnosis, and classification. J Am Acad Dermatol 2013:69:329-40 